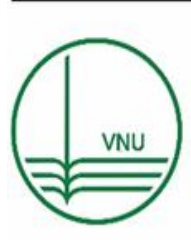

VNU Journal of Science: Legal Studies Journal homepage: https://js.vnu.edu.vn/LS

\title{
Review Article \\ Corporate governance in South Korean laws: Some suggestions for Vietnam
}

\author{
Phan Thi Thanh Thuy* \\ VNU School of Law, Vietnam National University, Hanoi, \\ 144 Xuan Thuy, Cau Giay, Hanoi, Vietnam \\ Received 22 January 2020 \\ Revised 17 March 2020; Accepted 26 July 2020
}

\begin{abstract}
Having an advanced legal framework for corporate governance is always one of the most prerequisites for effective business operation of joint stock companies. Being aware of this issue, since the first enactment in 1990, enterprise law in Vietnam has been consecutively improved and newly promulgated to absorb the OECD modern principles of corporate governance and good international practices, particularly from the developed countries which have successful economic cooperation with Vietnam in Asia. This article will focus on exploring and analyzing and making comments on the legal framework and corporate structures of joint stock company regulated in Korean Commercial Code. In term of comparison with those similar elements in Vietnamese Enterprise Law 2014, the article will also make recommendations as suggestions for the improvement of corporate governance law in the country.
\end{abstract}

Keywords: joint stock company, corporate governance, corporate structures, general meeting of shareholders, board of directors, independent directors.

\footnotetext{
* Corresponding author.

Email address: thuyptt@vnu.edu.vn

https://doi.org/10.25073/2588-1167/vnuls.4302
} 


\title{
Quản trị công ty cổ phần theo pháp luật Hàn Quốc: một vài gợi ý cho Việt Nam
}

\author{
Phan Thị Thanh Thủy* \\ Khoa Luật, Đại học Quốc gia Hà Nội, 144 Xuân Thủy, Cầu Giấy, Hà Nội \\ Nhận ngày 22 tháng 01 năm 2019 \\ Chỉnh sửa ngày 17 tháng 3 năm 2019; Chấp nhận đăng ngày 26 tháng 6 năm 2019
}

\begin{abstract}
Tóm tắt: Có một khung khổ pháp luật quản trị công ty cổ phần tiên tiến luôn là một trong những tiền đề quan trọng nhất cho hoạt động kinh doanh hiệu quả của công ty. Ý thức được điều này, kể từ khi ban hành lần đầu tiên năm 1990 đến nay, Luật doanh nghiệp Việt Nam liên tục được sửa đổi và ban hành mới để tiếp thu những nguyên tắc quản trị công ty tiến bộ của $\mathrm{OECD}$ cũng như những thông lệ quản trị tốt của các quốc gia trên thế giới, đặc biệt là những đất nước phát triển mà Việt Nam có quan hệ hợp tác kinh tế thành công. Bài viết này sẽ tập trung vào tìm hiểu và phân tích, đưa ra những bình luận về khung khổ pháp luật và cấu trúc quản trị công ty của Hàn Quốc trong sự so sánh với những cấu trúc tương đồng ở Việt Nam. Từ đó, bài viết cũng đưa ra nhưng nhận xét mang tính gợi ý để đóng góp cho công cuộc hoàn thiện pháp luật về quản trị công ty Việt Nam.
\end{abstract}

Tù khóa: công ty cổ phần, quản trị công ty, cấu trúc quản trị, đại hội đồng cổ đông, hội đồng quản trị, giám đốc độc lập.

\section{Mở đầu}

Từ những năm 1960 của thế kỷ XX, nền kinh tế Hàn Quốc đã phát triển mạnh mẽ và được thế giới vinh danh là một trong bốn nền kinh tế mới và phát triển nhanh nhất châu Á cùng với Nhật Bản, Hồng Kông và Đài Loan. Mặc dù trải qua khá nhiều biến động chính trị cũng như khủng hoảng kinh tế, Hàn Quốc vẫn được đánh giá là một trong những nền kinh tế đầu tầu và có những doanh nghiệp có nền quản trị doanh nghiệp thuộc hàng tốt nhất của khu vưc Đông Á [1]. Một trong trong những yếu tố cơ bản góp phần làm nên thành công này là Hàn Quốc có khung khổ pháp luật thương mại nói chung và pháp luật quản trị công ty nói riêng hiện đại, linh hoạt và liên tục được cải cách thông qua nhiều lần sửa đổi bổ sung để cập nhật các nguyên tắc quản trị hiện đại và đáp ứng nhu cầu phát triển của kinh tế xã hội.
Đặc biệt sau khủng hoảng tài chính châu Á 1997, nhận thức được những lỗ hổng trong quản trị công ty cổ phần (CTCP), Hàn Quốc đã có những cải cách mạnh mẽ về khung khổ pháp luật quản trị công ty để gia tăng hiệu quả hoạt động của nền kinh tế. Để làm được điều này, các nhà lập pháp đặc biệt chú trọng đến thiết lập cơ chế quản trị minh bạch, có trách nhiệm giải trình cao, nhưng vẫn linh hoạt thông qua phân cấp quản lý, phân công chức năng, nhiệm vụ rõ ràng giữa các cấu trúc quản trị công ty, tăng cường giám sát nội bộ và mở rộng quyền cho cồ đông thiểu số.

Bài viết này sẽ cung cấp một cái nhìn khái quát về pháp luật điều chỉnh và cấu trúc quản trị CTCP Hàn Quốc. Từ đó sẽ tiến hành so sánh với các cấu trúc tương đồng trong quản trị công ty theo pháp luật Việt Nam và đưa ra một số đề xuất có tính gợi mở để hoàn thiện khung khổ pháp luật

\footnotetext{
* Tác giả liên hệ.

Địa chỉ email: thuyptt@vnu.edu.vn

https://doi.org/10.25073/2588-1167/vnuls.4302
} 
quản trị công ty Việt Nam trong bối cảnh Luật Doanh nghiệp (LDN) 2014 đang được sửa đổi.

\section{Khái quát về khung khổ pháp luật quản trị công ty Hàn Quốc}

Hệ thống pháp luật Hàn Quốc về cơ bản thuộc về dòng họ Civil law, tuy nhiên, sau Chiến tranh Thế giới thứ hai, do ảnh hưởng của mối quan hệ đồng minh đặc biệt với Hoa Kỳ, pháp luật thương mại Hàn Quốc thể hiện sự du nhập và pha trộn hài hòa giữa các yếu tố của Civil law và Common law, đặc biệt là mang dấu ấn của luật công ty Mỹ [2]. Tại quốc gia này, Bộ luật Dân sự (Civil Code) điều chỉnh tất cả các vấn đề cơ bản của quan hệ hợp đồng tư nói chung, các vấn đề thuộc về thương nhân và hành vi thương mại được điều chỉnh bởi Luật Thương mại (Commercial Act). Mặc dù được cơ quan lập pháp gọi một cách khiêm tốn là "Luật" (Act), nhưng do tính chất pháp điển hóa cao, có phạm vi điều chỉnh rộng bao quát nhiều lĩnh vực thương mại và khối lượng đồ sộ các điều luật chứa đựng các quy định chi tiết, có tính áp dụng trực tiếp, Luật Thương mại Hàn Quốc thực sự là xứng đáng là một "Bộ luật" theo quan niệm hiện đaị, đó là: “...không chỉ là một tập hợp của các đạo luật thành văn đang tồn tại, mà còn chưa đưng vô số nhũng quy định bất thành văn về môt chủ đề, được ban hành mới nhu một hệ thống pháp luật hoàn chinh" [3]. Vì vậy nó có tên gọi quốc tế phổ biến là Bộ luật Thương mại Hàn Quốc (Commercial Code of Korea - KCC).

Kể từ lần đầu tiên được ban hành năm 1963 đến nay, $\mathrm{KCC}$ đã liên tiểp được sửa đổivà bổ sung để đáp ứng những thay đồi của môi trường kinh doanh. Sau khủng hoảng kinh tế châu Á năm 1997, Hàn Quốc rất chú trọng vào cải cách hoạt động quản trị CTCP đại chúng để tăng cường tính minh bạch, trách nhiệm giải trình và hiệu quả hoạt động. Đặc biệt từ khi Hàn Quốc chính thức trở thành một thành viên của Tổ chức Hợp tác và Phát triển Kinh tế (OECD) năm 2009 đến nay, Bộ luật thương mại hiện hành đã được bổ sung sửa đổi 8 lần, tập trung vào các mục tiều chủ yếu là đáp ứng sự thay đổi nhanh chóng của môi trường kinh doanh, cập nhật những hành vi thương mại hiện đại, khuyến khích thương mại công bằng và rất chú trọng cải thiện các quy định về quản trị công ty [4].

Về tổng thể, Bộ luật hiện hành (lần sửa đổi gần nhất năm 2015) gồm có 935 điều, chưa kể các phụ lục giải thích kèm theo, được chia làm 5 phần bao gồm: Những quy định chung, Hành vi thương mại, Công ty, Bảo hiểm, Thương mại hàng hải và Vận chuyển hàng không [5]. Phần III của KCC tập trung vào các quy định về công ty, trong đó có chế định về công ty cổ phần (CTCP) được xem là nền tảng pháp lý chính của quản trị công ty. Ngoài ra, các khía cạnh về giao dịch vốn, thực thi giám sát nội bộ, thực hiện quyền của cổ đông và kiểm toán trong quản trị $\mathrm{CTCP}$ đại chúng còn bị điều chỉnh bởi các luật khác Luật về Dịch vụ đầu tư và Thị trường vốn, Luật Chứng khoán và Giao dịch chứng khoán, Luật Kiểm toán độc lập.

Những quy định cơ bản của chế định CTCP nằm toàn bộ trong Chương 4 , Phần 3 của $\mathrm{KCC}$ gồm có 255 điều luật (từ Điều 288 đến Điều 542). Chương này điều chỉnh tất cả các vấn đề liên quan, bao gồm các vấn đề về thành lập và hoạt động của các cấu trúc quản trị công ty, về chuyển nhượng, giao dịch cổ phần và tái cấu trúc của CTCP. Để đảm bảo tính khoa học và tính hữu dụng, Chương 4 được chia được chia thành nhiều mục (Section) điều chỉnh những nhóm vấn đề nhất định. Ví dụ. Mục 2 Chương 4, quy định về Cổ phần, Mục 3 quy định về các cấu trúc quản trị CTCP.

Thoạt nhìn, toàn bộ $\mathrm{KCC}$ và cả Chương 4 về CTCP đều có cấu trúc khá đồ sộ, các điều luật hầu hết đều dài và có vẻ phức tạp, khó hiểu so với cấu trúc rất đơn giản của $\mathrm{LDN}$ Việt Nam, nhưng thực tế khi tìm hiểu kỹ lại thấy cách cấu trúc này thể hiện tính khoa học, tính logic, thuận tiện cho tra cứu và sử dụng. Đặc biệt, các điều luật được soạn thảo rất công phu, chứa đựng các quy định có tính hướng dẫn, giải thích rất rõ ràng, chi tiết và có tính áp dụng trực tiếp. Trong mỗi điều luật, đều có ghi chú rõ ràng về nội dung, số lần và hiệu lực của những lần bồ sung sửa đồi (nếu có). Ví dụ, bên cạnh Điều 393 về "Hoãn và Tiếp tục cuộc họp HĐQT”, còn có Điều 393-2 
về “Các ủy ban trong HĐQT”, được chú thích là điều luật được bổ sung vào Bộ luật hiện hành bởi Đạo luật sửa đổi số 6086, ngày 31/12/ 1999. Cách thức làm luật khoa học và cặn kẽ này làm cho người đọc hiểu rõ về ý nghĩa và tầm quan trọng của các điều luật khi tìm hiểu và áp dụng.

KCC không cần chờ hàng loạt các văn bản pháp quy được ban hành sau đó hướng dẫn việc thực thi pháp luật như luật doanh nghiệp và các đạo luật khác ở Việt Nam. Tuy nhiên, trong những trường hợp nhất định, Bộ luật cũng trao quyền cho Tổng thống được ban hành các Nghị định hướng dẫn thi hành luật (Nghị định Tổng thống) để giải thích, hướng dẫn một số điều khoản nhất định để làm tăng tính linh hoạt và phù hợp với sự thay đổi của hoàn cảnh trong nước và thị trường thương mại quốc tế mà không làm mất đi tính ổn định của KCC. Chẳng hạn, Điều 5424 (Công bố thông tin về triệu tập ĐHĐCĐ) quy định: công ty đại chúng khi triệu tập họp ĐHĐCĐ, phải công bố mục đích cuộc họp, thành phần tổ chức và các thông tin có liên quan khác nếu Nghị định có yêu cầu. Nhìn chung khung khổ pháp luật cho quản trị CTCP ở Hàn Quốc có tính ổn định và hiệu lực pháp lý thống nhất nhưng vẫn đảm bảo sự linh hoạt.

\section{Khái niệm đặc điểm và phân loại công ty cổ phần Hàn Quốc}

\section{Khái niệm và đặc điểm công ty cổ phần}

KCC không có định nghĩa riêng về CTCP mà chỉ đưa ra định nghĩa chung về công ty như sau: "Công ty là một tổ chức kinh doanh được thành lập với mục đích tham gia vào các hoạt động thương mại và bất kỳ hoạt động tạo ra lợi nhuận nào khác.” (Điều 169). Bộ luật cũng chỉ rõ "Các công ty được phân thành năm loại, cụ thể là các công ty hợp danh, công ty hợp danh hữu hạn, công ty trách nhiệm hữu hạn, CTCP và công ty hữu hạn.” (Điều 170). Có thể tổng hợp khái niệm về CTCP từ các quy định của $\mathrm{KCC}$ như sau:

- Vốn được chia làm nhiều phần bằng nhau gọi là cổ phần. Công ty có quyền xác định mệnh giá cổ phần nhưng phải có giá trị ít nhất 100 won (Điều 329);

- Cổ đông có thể là cá nhân hay tổ chức, $\mathrm{KCC}$ không có quy định về số lượng tối thiểu và tối đa cổ đông, do đó có thể suy ra CTCP có ít nhất một cổ đông và không hạn chế số lượng tối đa [6].

- Cổ đông chỉ trách nhiệm hữu hạn trong phạm vi số vốn mà họ góp vào công ty (Điều 331).

- Cổ phần có thể được tự do chuyển nhượng tuy phải được sự đồng ý của Hội đồng quản trị và việc chuyển nhượng này không chống lại lợi ích của công ty (Điều 335).

- CTCP có thể phát hành cổ phần (Điều 416) và trái phiếu trên thị trường (Điều 469).

\section{Phân loại công ty cổ phần}

- Dựa vào quy mô và khả năng huy động vốn CTCP được chia làm 2 loại là CTCP đại chúng (Listed company) và $\mathrm{CTCP}$ thông thường.

CTCP đại chúng được KCC giải thích là công ty có phiếu phát hành đã được niêm yết trên thị trường chứng khoán ((Điều 542-2). Giải thích này cũng hoàn toàn phù hợp với định nghĩa về công ty đại chúng tại Điều 2(13).1 Luật Chứng khoán và Giao dịch chứng khoán (Luật Chứng khoán - Securities and Exchange Act). Tương tự như ở Việt Nam, Luật Chứng khoán sẽ quy định các tiêu chí, điều kiện để công ty đại chúng giao dịch vốn trên thị trường chứng khoán. Tuy nhiên, trong KCC cũng có một mục riêng Mục 13-Các truờng hợp đặc biệt đối với CTCP đại chúng để quy định về các hoạt động quản trị công ty đặc thù mà $\mathrm{CTCP}$ đại chúng phải tuân thủ như quy trình kiểm soát nội bộ và theo dõi biến động cổ phần sở hữu bởi các cổ đông trong công ty.

Như vậy, các CTCP không hội đủ các tiêu chuẩn để xác định là công ty đại chúng là $c o ̂ n g$ ty cổ phần thông thuoờng, hoạt động theo các quy định của KCC và các luật có liên quan.

\section{Về cấu trúc quản trị của công ty cổ phần Hàn Quốc}

Do ảnh hưởng sâu của luật công ty Mỹ, KCC chỉ quy định về mô hình CTCP có cấu trúc quản 
trị một tầng cho cả CTCP đại chúng và $\mathrm{CTCP}$ thông thường. Theo đó, trong bộ máy quản trị không tồn tại một cơ quan giám sát nội bộ do ĐHĐCĐ bổ nhiệm và độc lập với Hội đồng quản trị. Cũng không có sự tách biệt giữa HĐQT- cơ quan đại điện cho các chủ sở hữu công ty và ban giám đốc điều hành như trong mô hình quản trị hai tầng truyền thống của Đức hay mô hình quản trị CTCP hỗn hợp trong Luật Doanh nghiệp 2014 của Việt Nam [7].

Mặc dù vẫn có một số khác biệt nhất định so với mổ hình quản trị công ty Mỹ, nhìn chung cấu trúc quản trị CTCP Hàn Quốc đều có những cơ quan quản trị quan trọng và cơ bản nhất gồm: Đại hội đồng cồ đông (ĐHĐCĐ), Hội đồng quản trị (HĐQT), Giám đốc điều hành và giám đốc độc lập, Kiểm toán. Các chức danh khác thường thấy trong mô hình CTCP Mỹ như Chủ tịch công ty, Thư ký công ty, Người quản lý vốn không có trong các quy định về thành lập công ty của KCC, tuy nhiên luật cũng không cấm các công ty bổ nhiệm các chức danh này, miễn là được ghi nhận trong Điều lệ thành lập công ty và được ĐHĐCĐ chấp nhận trong nghị quyết cuộc họp.

*Đại hộ đồng cổ đông (General meeting of shareholders): Theo thông lệ quốc tế, ĐHĐCĐ là cơ quan quản trị cao nhất trong công ty, bao gồm toàn thể các cổ đông sở hữu ít nhất một cổ phần hoặc bao gồm một số lượng cổ đông nhất định đủ để đại diện cho các cổ đông. Cơ quan này có đảm nhiệm vai trò bàn bạc và ra nghị quyết để quyết định những vấn đề thuộc thẩm quyền của ĐHĐCĐ do KCC hoặc do Điều lệ quy định. Thông thường đó là những vấn đề quan trọng nhất trong công ty như như chiến lược phát triển và kinh doanh, bổ nhiệm bộ máy quản trị công ty, định hướng quan hệ tài chính và kinh doanh của công ty, quyết định các vấn đề về chuyển nhượng, đầu tư tài sản, tái cấu trúc công ty, thông qua báo cáo tài chính của công ty vv...

Mặc dù ĐHĐCĐ được tổ chức theo những quy trình rất chặt chẽ từ khâu triệu tập đến cách thức tổ chức, biểu quyết, KCC cũng rất linh hoạt khi cho phép các thủ tục tổ chức đơn giản đối với những công ty có quy mô hoạt động nhỏ có vốn dưới 1 tỷ won; nếu giữa các cổ đông đã đạt được đồng thuận về cách thức tổ chức hội nghị, có thể gửi thư điện tử để triệu tập họp thay vì gửi văn bản qua đường bưu điện như đối với công ty lớn (Điều 363).

\section{ii) Về phưong thức ra nghị quyết ĐHĐCĐ:} Tùy thuộc quy định của luật và của Điều lệ và tính chất, tầm quan trọng của các vấn đề đưa ra quyết định tại ĐHĐCĐ mà tỉ lệ phiếu thuận để thông qua Nghị quyết phải là đa số, siêu đa hoặc thậm chí phải đạt đồng thuận của tất cả các cổ đông (Điều 361, 371). Tuy nhiên các quy định trong Điều lệ chỉ được phép "chặt" hơn chứ không được phép nới lỏng hơn luật [8]. Chẳng hạn, công ty không thể mở rộng diện đối tượng được lựa chọn để bổ nhiệm làm Giám đốc độc lập của công ty bằng cách bỏ bớt đi một trong 7 tiêu chuẩn bổ nhiệm chức danh này quy định tại Điều 542.

*Hội đồng quản trị (Board of Directors) và các giám đốc thành viên: Về bản chất HĐQT là cơ quan thường trực do ĐHĐCĐ bầu ra, để quyết định các vấn đề về quản lý điều hành công ty giữa các kỳ họp ĐHĐCĐ (Điều 382 - 389).

Thông thường, HĐQT số lượng thành viên tối thiểu là 3 . Tuy nhiên để tạo sự năng động cho các CTCP nội bộ, Bộ luật Thương mại (KCC) quy định công ty có vốn dưới 1 tỷ won có thể chỉ bổ nhiệm 1-2 giám đốc mà không cần có HĐQT (Điều 383).

HĐQT có cấu trúc đa tầng, các giám đốc thành viên được chia làm nhiều loại chức danh để thực hiện các chức năng nhiệm vụ khác nhau bao gồm Giám đốc đại đại diện theo pháp luật và Giám đốc điều hành, đều được bổ nhiệm và bãi miễn tại cuộc họp của ĐHĐCĐ và ghi nhận trong nghị quyết. Là những chức danh quản lý cấp cao do ĐHĐCĐ bổ nhiệm, tất cả các giám đốc thành viên đều phải tuân thủ các nghĩa vụ chung của người quản lý được các cổ đông và công ty ủy quyền (Fiduciary duty) [9]. Trong đó, các nghĩa vụ hàng đầu là nghĩa vụ cẩn trọng khi ra các quyết định trong công ty (Điều 340), nghĩa vụ trung thành và hành động vì lợi ích cao nhất của công ty (Điều 382). Đặc biệt, nghĩa vụ bảo mật còn yêu cầu các giám đốc giữ bí mật đối với các 
hoạt động của công ty ngay cả khi đã về hưu (Điều 382).

KCC cho phép HĐQT có thể bổ nhiệm hai hay nhiều giám đốc đại diện theo pháp luật cho công ty, trừ phi số lượng chức danh này đã được đã được ấn định trong Điều lệ (Điều 389).

Giám đốc điều hành: là những người quản lý cao cấp nhất có chức năng điều hành trực tiếp, hàng ngày các hoạt động kinh doanh và hoạt động quản lý công ty. Trường hợp có từ hai giám đốc điều hành trở lên, HĐQT phải bổ nhiệm một người trong số đó là giám đốc đại diện. Nếu chỉ có một giám đốc điều hành, người này sẽ kiêm luôn vai trò giám đốc đại diện (Điều 408). HĐQT cũng sẽ một người đảm nhiệm vai trò chủ tịch công ty để chủ trì các cuộc họp HĐQT (Điều 408).

*Giám đốc bên ngoài (Outside Directors) trong CTCP Hàn Quốc có những vị trí tương tự và tên gọi thay thế khác như Giám đốc độc lập (Independentdirectors) tại Ấn Độ, Singapre, Việt Nam hay Giám đốc không điều hành (Nonexecutive directors) tại Mỹ. Theo thông lệ quốc tế, các chức danh này là những vị trí quản trị đặc biệt. Về bản chất, họ không phải là thành viên điều hành các hoạt động hàng ngày của công ty. Họ phải đảm bảo tính độc lập, không bị khuynh loát bởi cổ đông lớn và những người quản lý khác về quan hệ việc làm, quan hệ tài chính và cá nhân khi đưa ra quyết định. Giám đốc độc lập (Giám đốc bên ngoài) cũng không được sở hữu một lượng cổ phần đủ lớn đến mức có thể bị các lợi ích cá nhân chi phối. Chính vì vậy, họ không được hưởng lương mà chỉ nhận một khoản thù lao khi tham gia các cuộc họp của HĐQT.

Về mặt luật pháp, tất cả các giám đốc độc lập cũng như giám đốc điều hành đều phải thực hiện các nghĩa vụ chung được cổ đông ủy quyền ủy quyền đã đề cập đến ở trên, đó là ra các quyết định cẩn trọng, trung thức, hành động thiện chí và vì lợi ích tốt nhất của công ty. Tuy nhiên do đóng vai trò khác với giám đốc điều hành, các giám đốc bên ngoài tham gia vào HĐQT với tư các là các chuyên gia độc lập, đóng góp những ý kiến có tính đa đạng, khách quan để giúp các thành viên điều hành của $\mathrm{HĐQT}$ điều hòa các xung đột lợi ích với giữa công ty với các cổ đông và giữa các giám đốc điều hành với nhau. Chẳng hạn, các Giám đốc độc lập đưa ra góp ý về mức lương của thành viên điều hành, về việc lựa chọn nhân sự để bổ nhiệm chức danh kiểm toán, về cách thức công bố thông tin về tình hình hoạt động kinh doanh,...và những vấn đề liên quan khác nhằm đảm bảo cho các giám đốc điều hành thực hiện nhiệm vụ một cách đúng đắn, sáng suốt [10].

Sau khủng hoảng tài chính châu Á 1997, vai trò của Giám đốc bên ngoài trong việc làm tăng tính minh bạch trong hoạt động của công ty được đề cao tại Hàn Quốc. Trước yêu cầu cải cách ngặt nghèo của Quỹ tiền tệ Quốc tế (IMF) đối với cung cách hoạt động của công ty và yêu cầu nâng cao tính minh bạch, trách nhiệm giải trình, KCC đã nhanh chóng tiếp thu các thông lệ quốc tế về quản trị tốt và quy định giám đốc bên ngoài phải là thành phần bắt buộc trong $\mathrm{HĐQT}$ của $\mathrm{CTCP}$ đại chúng và được khuyến khích sự có mặt của thành phần này trong $\mathrm{CTCP}$ thông thường [11].

Về cơ cấu: Đối với CTCP nói chung, trong thành phần của HĐQT phải có ít nhất là $25 \%$ thành viên là giám đốc bên ngoài, không trực tiếp làm các công việc liên quan đến cổ đông và điều hành công ty. Đối với CTCP đại chúng, số lượng giám đốc bên ngoài phải có ít nhất là 3 người và chiếm trên $50 \%$ số lượng thành viên hội đồng (Điều 542). Phối hợp chặt chẽ với KCC, Luật Chứng khoán và Giao dịch chứng khoán cũng quy định rằng $\mathrm{CTCP}$ đại chúng phải có ít nhất $25 \%$ thành viên HĐQT là Giám đốc bên ngoài. Đối với công ty có số vốn từ 2 tỷ won trở lên cần có Ủy ban đề xuất Giám đốc độc lập để giới thiệu ứng viên cho $H Đ Q T$ và phải chịu trách nhiệm về việc đề xuất này (Điều 542).

Để đảm bảo tính độc lập, khách quan của Giám đốc bên ngoài trong việc đưa ra các ý kiến nhận xét và bỏ phiếu thông qua các quyết định của HĐQT, KCC quy định các tiêu chuẩn bổ nhiệm rất chặt chẽ, loại trừ các diện sau: vị thành niên, mất toàn bộ hoặc mất một phần năng lưc hành vi dân sự, bị tuyên bố phá sản chưa được phục hồi kinh doanh, vi phạm pháp luật hay thi hành án hình sự xong chưa được 2 năm, vẫn đang 
trong thời gian 2 năm kể từ ngày bị sa thải ở công ty, sở hữu quá $10 \%$ số lượng cổ phần phát hành hoặc cổ phần hiện hữu, người có quan hệ huyết thống, hôn nhân với các chức danh quản lý cao cấp của công ty, có khả năng tư lợi cao theo quy định của Nghị định của Tổng thống (Điều 542).

Tóm lại, HĐQT trong CTCP Hàn Quốc có tính đa dạng về thành phần, chức danh và nhiệm vụ nên đã tạo ra cơ chể linh hoạt, hỗ trợ lẫn nhau trong hoạt động để cùng hướng về mục tiêu chung là tăng tính minh bạch và trách nhiệm giải trình. Đặc biệt ở một góc độ kiểm tra lẫn nhau và cân bằng quyền lực trong nội bộ $\mathrm{HĐQT}$, các giám đốc bên ngoài còn đóng vai trò của người giám sát, cân chỉnh các quyết định và hoạt động quản lý của các giám đốc điều hành.

*Kiểm toán nội bộ, giống như ở mô hình quản trị công ty của Mỹ, KCC trao quyền giám sát các hoạt động tài chính của công ty cho bộ phận kiểm toán nội bộ được ĐHĐCĐ bổ nhiệm theo quy định bắt buộc của pháp luật để thực hiện chức năng giám sát hoạt động của HĐQT. Mục tiêu của hoạt động kiểm toán là bảo đảm tính minh bạch và đảm bảo tuân thủ Điều lệ trong các hoạt động tài chính của công ty [12].

Kiểm toán viên theo pháp luật (Statutory auditor) được bổ nhiệm tại cuộc họp ĐHĐCĐ. Để bảo đảm các kiểm toán viên này độc lập trong chuyên môn, không bị các cổ đông lớn chi phối, KCC quy định cổ đông nắm giữ trên $3 \%$ cổ phần sẽ không được giới thiệu để bổ nhiệm làm kiểm toán viên; ngược lại các cổ đông nắm giữ trên $3 \%$ cổ phần không có quyền bỏ phiếu lựa chọn kiểm toán viên (Article 409(2). CTCP quy mô nhỏ có vốn dưới 1 tỷ won không bắt buộc phải bổ nhiệm kiểm toán (Điều 409).

Kiểm toán viên có quyền giám sát các hoạt động tài chính của do các giám đốc tiến hành dưới danh nghĩa công ty, yêu cầu các chuyên gia hỗ trợ khi cần xác định thông tin về các khoản chi của công ty. Kiểm toán viên cũng có quyền yêu cầu triệu tập cuộc họp HĐQT và ĐHĐCĐ để lấy thông tin giám sát và báo cáo kết quả giám sát của mình (Điều 412, 412).

Để buộc các kiểm toán viên thực hiện nghiêm túc trách nhiệm giám sát và báo cáo của mình, KCC quy định nếu kiểm toán viên thiếu cẩn trọng, lơ là trong thực hiện nhiệm vụ giám sát sẽ phải chịu trách nhiệm liên đới về các thiệt hại cùng với các giám đốc có hành vi sai trái trước công ty và người thứ ba (Điều 414).

Đối với CTCP đại chúng, luật khuyến khích thành lập Ban kiểm toán nội bộ có số lượng thành viên ít nhất là 03 kiểm toán viên trở lên, trong đó có ít nhất $2 / 3$ kiểm toán viên là giám đốc độc lập (Điều 409 và Điều 415). Nhằm ngăn ngừa việc sa thải không chính đáng, $\mathrm{KCC}$ quy định rằng cần phải có số phiếu thuận ít nhất bằng 2/3 tổng số thành viên, HĐQT mới được bãi miễn một thành viên Ban kiểm toán. (Điều 415).

Kiểm toán độc lập: Theo quy định của đạo luật về Kiểm toán độc lập đối với CTCP sửa đổi năm 2017, các CTCP đại chúng và có quy mô lớn theo tiêu chí do luật này đặt ra thuộc diện phải áp dụng thêm chế độ kiểm toán độc lập do công ty kiểm toán bên ngoài tiến hành [13].

*Vai trò của cổ đông thiểu số

Mặc dù nhóm các cổ đông thiểu số không tạo nên một cấu trúc quản trị riêng, nhưng sẽ là thiếu sót khi nghiên cứu về quản trị CTCP mà không đề cập đến vai trò của nhóm cổ đông đặc biệt này bởi lẽ bảo vệ cổ đông thiểu số là một yếu tố cốt lõi để thực thi nguyên tắc bình đẳng giữa các cổ đông của OECD [14]. Là quốc gia thành viên OECD từ năm 1999, Hàn Quốc đã tuân thủ rất nghiêm túc và chuyển hóa thành công nguyên tắc về đối xử bình đẳng giữa các cổ đông và bảo vệ cổ đông thiểu số khỏi sự lấn át của các cổ đông lớn trong bộ luật thương mại của mình. KCC không đưa ra khái niệm cổ đông thiểu số mà có những quy định cụ thể về quyền của nhóm cổ đông này trong các tình huống cụ thể. Theo quy định của $\mathrm{KCC}$, cổ đông nắm giữ ít hơn $3 \%$ tồng số cổ phần phát hành và cổ phần lưu hành, được pháp luật trao cho một số quyền đặc biệt để tự bảo vệ lợi ích của mình và lợi ích của công ty trước các hành vi thao túng, khuynh loát của cổ đông lớn bao gồm: Quyền triệu tập và đề xuất nội dung cuộc họp ĐHĐCĐ (Điều 363-2(1), Quyền yêu cầu tòa án triệu tập họp ĐHĐCĐ bất thường trong trường hợp HĐQT không chấp nhận (Điều 366; Quyền yêu cầu công ty, hoặc 
nhân danh công ty khởi kiện các giám đốc điều hành và yêu cầu miễn nhiệm vì các hành vi được cho là sai trái (Điều 381), cổ đông sở hữu tổng số cổ phần ít hơn $1 \%$ cũng có quyền này (Điều 403)

Đặc biệt, đối với CTCP đại chúng được xếp hạng theo quy định của Luật Chứng khoán, cổ đông thiểu số chỉ cần sở hữu 15/1.000 trong thời hạn liên tục 6 tháng đã có quyền thực thi các quyền của cổ đông thiểu nói trên. Đối với các CTCP đại chúng được xếp hạng bởi Nghị định chỉ cần sở hữu một số lượng cồ phần rất nhỏ từ 25/10.000 tổng số cổ phần đã có thể thực hiện các quyền của cổ đông nhỏ và cả cổ đông thông thường (Điều 542).

\section{Nhận xét và một số gọi ý cho Việt Nam}

Qua tìm hiểu về pháp luật quản trị CTCP Hàn Quốc và các cấu trúc quản trị công ty có thể thấy nổi lên một số vấn đề có tính chất gợi ý để học tập kinh nghiệm cải cách khung khổ pháp luật về quản trị CTCP ở Việt Nam như sau:

*Về cách thức cấu trúc của pháp luật thưong mại nói chung và pháp luật về quản trị công ty nói riêng: Có thể thấy KCC chính là một tổng thể pháp luật thương mại thống nhất, có sự kết hợp logic và hài hòa giữa các quy định chung, chế định thương nhân, thương mại hàng hóa và dịch vự, chế định luật công ty và một số các chế định về thương mại dịch vụ trong các lĩnh vực đặc thù, có tính chuyên ngành như bảo hiểm, đường biển, hàng không.

Về kỹ thuật lập pháp, KCC là một bộ luật, tuy đồ sộ nhưng có cấu trúc khoa học và thuận tiện cho việc tìm hiểu và áp dụng luật. Cấu trúc này giúp tránh được các quy định chồng chéo, xung đột, thậm chí có cách hiểu và giải thích trái ngược đối với cùng một khái niệm trong trường hợp nhiều đạo luật riêng lẻ cùng điều chỉnh một quan hệ pháp luật thương mại như đang tồn tại ở Việt Nam hiện nay [15].

Đặc biệt, KCC có những quy định cụ thể về những trường hợp có thể được giải thích, mở rộng quy định bằng Nghị định của Tổng thống. Điều này giúp củng cố tính thống nhất và hiệu lực ổn định, tính áp dụng trực tiếp của Bộ luật, đồng thời không làm phát sinh thêm một khối lượng đồ sộ các văn bản pháp quy bao gồm luật và nghị định để hướng dẫn thi hành luật như tình trạng lập pháp và lập quy hiện tại ở Việt Nam.

*Về phạm vi và đối tượng điều chỉnh của pháp luật quản trị công ty cổ phần

Khác với KCC, trong suốt các quy định của LDN 2014 và các phiên bản trước đó của Việt Nam, không có bất cứ một quy định nào đề cập đến cấu trúc quản trị CTCP đại chúng, mà trao toàn bộ quyền cho Luật Chứng khoán 2006. Điều này có thể đã đưa ra một thông điệp sai, có tính mặc định rằng LDN 2014 không có giá trị áp dụng đối với công ty đại chúng. Trong khi đó sự thực là các quy định về cấu trúc quản trị CTCP phải được áp dụng chung, chỉ một số trường hợp đặc biệt có liên quan đến các điều kiện chặt chẽ của giao dịch chứng khoán mới do Luật Chứng khoán điều chỉnh. Do đó vấn đề phạm vi và đối tượng điều chỉnh của LDN 2014 bao gồm cả CTCP đại chúng phải được chỉ rõ trong luật sửa đổi.

*Về mô hình quản trị một tầng và các cấu trúc quản trị tương ưng

Do có sự tiếp nhận mô hình quản trị công ty một tầng của Mỹ ngay từ những năm 1960 và đã trải qua rất nhiều lần bổ sung sửa đổi, cho đến nay cấu trúc quản trị đa tầng, đa chức năng, có tác dụng giám sát cân bằng quyền lực giữa các chức danh quản trị trong CTCP Hàn Quốc của KCC đã tương đối hoàn thiện.

Khác với Hàn Quốc, mô hình quản trị một tầng mới được công nhận trong LDN 2014 của Việt Nam. Do tính mới và có phẩn chưa hiểu rõ ý nghĩa triết lý và tính chất pháp lý của mô hình này nên các quy định của LDN 2014 còn nhiều thiếu hụt, rất khó cho việc triển khai áp dụng trong thực tế. Cụ thể, hai cấu trúc quản trị nổi bật nhất của mô hình một tầng là "thành viên độc lập HĐQT" và "Ban kiểm toán" chưa được quy định rõ và chú trọng trong luật doanh nghiệp Việt Nam.

Thư nhất, cách thức tổ chức ĐHĐCĐ của $\mathrm{CTCP}$ của $\mathrm{KCC}$ rất linh hoạt tùy theo quy mô của công ty mà có những thủ tục rút gọn miễn là có sự đồng thuận. Trong khi đó LDN 2014 chỉ quy định cùng một thủ tục ĐHĐCĐ cho tất cả các 
CTCP có quy mô khác nhau. Điều này có thể làm cho các cuộc họp ĐHĐCĐ trở nên chậm chạp, khó khăn hơn đối với công ty có quy mô nhỏ.

Thư hai, So với KCC, LDN 2014 của Việt Nam chưa có những quy định rõ ràng để tạo ra tính đa tầng, đa chức năng của thành viên HĐQT. Luật doanh nghiệp hiện hành không đề cập đến khái niệm thành viên (giám đốc) điều hành trong $\mathrm{HĐQT}$ và không phân định chức năng, cách thức thực hiện nhiệm vụ của của các loại thành viên điều hành và không điều hành trong công ty, do đó khái niệm "Thành viên độc lập HĐQT" mới đưa vào luật, thậm chí còn xa lạ, đang đặt ra nhiều câu hỏi chưa được trả lời về bản chất, vai trò, chức năng nhiệm vụ của chức danh này. Thêm vào đó, Luật có những quy định về tiêu chuẩn thành viên độc lập HĐQT tại Khoản 2 Điều 151 nhưng lại không có bất kỳ một quy định nào về phạm vi và giới hạn trách nhiệm của họ trong HĐQT nên khó có thể áp dụng mô hình này trên thực tiễn.

Thư $b a$, Mặc dù khuyến khích mô hình quản trị một tầng như KCC, LDN 2014 lại hoàn toàn thiếu hụt các quy định về chức năng giám sát tài chính công ty của kiểm toán. Cụ thể, không có quy định về vai trò và trách nhiệm của kiểm toán viên nội bộ trong tại CTCP thông thường; thêm vào đó, "Ban kiểm toán nội bộ" thuộc HĐQT trong mô hình có thành viên độc lập HĐQT chỉ được đề cập một lần duy nhất trong Điểm $b$, Khoản 2 Điều 134 LDN 2014. Trong suốt đạo luật cũng không hề có thêm một quy định nào về các thức tuyển chọn, và vận hành cơ quan giám sát nội bộ đặc biệt này. Các mâu thuẫn này đang gây ra những bối rối cho các nhà đầu tư và người quản lý về cách thức tổ chức và vận hành $\mathrm{CTCP}$ có mô hình quản trị một tầng ở Việt Nam.

Tóm lại, do không có đầy đủ các hướng dẫn về cách thức thành lập và vận hành của các cấu trúc quản trị nên mô hình quản trị một tầng mặc dù hấp dẫn về tính linh hoạt, độ phản ứng nhanh của HĐQT trước các cơ hội kinh doanh, nhưng lại thiếu tính khả thi ở Việt Nam. Có lẽ nguyên nhân chính của sự hạn chế này là do các nhà làm luật mới du nhập được phần hình thức cấu trúc mà chưa nắm được triết lý về ý nghĩa, vai trò và cách thức hoạt động của các cấu trúc quản trị đặc biệt như thành viên độc lập hội đồng quản trị, kiểm toán viên và Ban kiểm toán. Hiện tại, trong Dự thảo luật sửa đổi Luật Doanh nghiệp mới nhất đăng tải trên website của Quốc Hội [16] đã chú trọng hơn đến thẩm quyền thành lập, vai trò và cách thức hoạt động của Ủy ban kiểm toán trực thuộc HĐQT (Điều 156a), nhưng lại không đề cập đến trách nhiệm khi xảy ra sai phạm. Đặc biệt, Dự thảo cũng không đề cập đến vai trò của kiểm toán viên theo luật định của công ty. Vai trò, chức năng, nhiệm vụ của thành viên độc lập HĐQT cũng được trao toàn bộ cho Điều lệ công ty quyết định (Khoản 5, Điều 150 của Dự thảo) mà không có hướng dẫn từ luật.

\section{*Về mức độ bảo vệ cổ đông thiểu số}

So với $\mathrm{KCC}$, diện xác định cổ đông thiểu số trong công ty của LDN 2014 là rất hẹp. Trong khi KCC xác định những cổ đông sở hữu dưới $3 \%$ cổ phần được sử dụng những quyền đặc biệt để bảo vệ lợi ích chính đáng của mình và lợi ích của công ty, LDN 2014 lại quy định cổ đông phải sở hữu tổng số cổ phần từ $10 \%$ trở lên, thậm chí sở hữu liên tục trong 6 tháng mới có quyền đề cử người vào $\mathrm{HĐQT}$ và ban kiểm soát, yêu cầu được thông tin sâu về hoạt động của công ty, yêu cầu triệu tập họp ĐHĐCĐ (Khoản 2 Điều 114). Rõ ràng là Luậ̣t đang làm giảm khả năng kiểm soát và cân bằng quyền lực giữa các nhóm cổ đông trong công ty. Thêm vào đó, ngoài quyền khởi kiện, Luật cũng không có quy định về các quyền đặc biệt trong quản trị công ty của cổ đông thiểu số có tỷ lệ sở hữu vốn dưới $1 \%$ trong CTCP đại chúng. Các quy định bất hợp lý này cần được nhanh chóng cải cách để mở rộng diện các cổ đông thiểu số và các quyền chính đáng của họ, bảo đảm nguyên tắc quyền bình đẳng của các cổ đông.

\section{Kết luận}

Qua phân tích và so sánh khung khổ pháp luật và cấu trúc quan trị của CTCP Hàn Quốc với pháp luật quản trị công ty và các cấu trúc tương ứng của Việt Nam có thể thấy pháp luật về quản trị CTCP ở Việt Nam hiện nay đang bộc lộ một 
số hạn chế cơ bản cần nhanh chóng cải cách. Thứ nhất, đó là hệ thống pháp luật thương mại mang tính nền tảng còn cồng kềnh và tản mạn, thậm chí còn có những quy định mâu thuẫn. Thư hai, khung khổ pháp luật về quản trị công ty mặc dù đã cố gằng tiếp thu tương đối nhanh các quy tắc quản trị công ty hiện đại của $\mathrm{OECD}$ và các thông lệ quản trị tốt của các quốc gia khác, nhưng còn bộc lộ những quy định chưa thấu đáo, chưa phù hợp về cách thức cấu trúc mô hình quản trị công ty một tầng, thiếu sự thống nhất và hài hòa nên hạn chế hiệu quả thi hành luật trên thực tiễn.

Để khắc phục kịp thời các hạn chế nói trên, giải pháp trước mắt là khắc phục ngay những quy định còn thiếu hụt và bất hợp lý về quản trị công ty trong luật bổ sung sửa đổi LDN 2014 hiện đang trong quá trình dự thảo. Về lâu dài, cần có một khung khổ quản trị công ty hoàn chỉnh, nằm trong một tổng thể hệ thống pháp luật thương mại tập trung thống nhất, có hiệu lực pháp luật cao và ổn định. Chính vì vậy, xu hướng xây dựng một bộ luật thương mại chung tương tự như KCC ở Việt Nam là một định hướng đúng đắn trong tương lai gần. Như vậy, Bộ luật Thương mại Hàn Quốc có thể là một trong những hình mầu hữu ích mà các nhà làm luật Việt Nam cần tham khảo.

\section{Tài liệu tham khảo}

[1] Park JD, Korea's Path of Development in Retrospect, trong sách Re-Inventing Africa's Development. Palgrave Macmillan, Cham 2019, (tr.180-201)

[2] Jin Oh Seung, Overview of Legal Systems in the Asia-Pacific Region: South Korea, trong Overview of Legal Systems in the Asia- Pacific Region (2004). Paper 6 tại:

http://scholarship.law.cornell.edu/lps_lsapr/6. (truy cập 22/2/2019)

[3] Black's Law Dictionary (10th Edition), in Co, Bryan A. Garner (Chief Editor), Editor. 2014, Thomson Reuters, tr. 312.

[4] Commercial Act of Korea tại:
http://law.go.kr/lsInfoP.do?lsiSeq=176698\&urlM ode=engLsInfoR\&viewCls=engLsInfoR\#0000 (truy cập 5/12/2019).

[5] Commercial Act of Korea, tlđd.

[6] Stock Company tại http://koreanlii.or.kr/w/index.php/Company?ckatt empt=1 ( truy cập 23/2/2020).

[7] Phan Thị Thanh Thủy, Bàn về tính minh bạch trong quản trị công ty cổ phần ở Việt Nam, Nghiên cứu Lập pháp, kỳ 1 tháng 1/2018, 53-55.

[8] Corporate Governance in Korea, International Financial Law Review, tại: https://www.iflr.com/Article/2027067/Corporategovernance-in-Korea.html (truy cập 22/12/2019).

[9] LDN 2014 gọi là trách nhiệm của người quản lý công ty cổ phần quy định tại Khoản 1 Điều 160 .

[10] Lucian a. Bebchuk \& Assaf Hamdan, Independent directors and controlling shareholders, University of Pennsylvania Law Review, 2016. Vol. 165,(6): p.1271-1280.

[11] Chun, K.H., Korea's Mandatory Independent Directors: Expected and Unexpected Roles, tại https://ssrn.com/abstract=2824303 P9-10 (truy cập 22/1/2020). August 2016,.

[12] Block, D.a.G., Anne-Marie, One-Tier vs. Two-Tier Board Structure: A Comparison Between the United States and Germany, Comparative Corporate Governance and Financial Regulation. https://scholarship.law.upenn.edu/fisch_2016/1 2016, p.6 (truy cập 22/2/2020).

[13] https://www.tmf-group.com/en/newsinsights/articles/2019/february/external-audit-act/.

[14] OECD, Nguyên tắc Đối xử bình đẳng giữa các cổ đông trong sách Các nguyên tắc quản trị công ty của OECD tại: https://www.oecd.org/daf/ca/corporategovernance principles/45034702.pdf, tr. 41-47;. 2004.

[15] Phan Thị Thanh Thủy, Chương 6, Pháp luật điều chỉnh hành vi kinh doanh ở Việt Nam, tr 251 - 257, trong sách Thể chế pháp luật kinh doanh Việt Nam trong bối cảnh hội nhập cộng đồng kinh tế ASEAN, Phan Thị Thanh Thủy, Chủ biên, NXB Đại học Quốc gia, 2019.

[16] Dự thảo Luật Doanh nghiệp (sửa đổi) tháng 3/2020 tại http://duthaoonline.quochoi.vn/DuThao/Lists/DT_ DUTHAO_LUAT/View_Detail.aspx?ItemID=177 3\&LanID=1811\&TabIndex=1 (24/3/2020). 